Мельник Н.Г.

кандидат філологічних наук, дочент КПІ ДВНЗ «Криворізький начіональний університет»

\title{
ТРАНСФОРМАЦІЯ РИС НАЦІОНАЛЬНОЇ МЕНТАЛЬНОСТІ В ЧУМАЦЬКІЙ ПІСЕННОСТІ
}

У статті виявлено і систематизовано традииї й ознаки національної ментальності у чумачькому фольклорі.

Аналіз чумачької пісенності дав можливість сформувати уявлення про психотип чумака.

Ключові слова: фольклор, чумаки, пісня.

В статье выявлено и систематизировано традичии и признаки национальной ментальности в чумачком фольклоре.

Анализ чумачкой песенности дал возможность сформулировать понятие о психотипе чумака.

Ключевые слова: фольклор, чумаки, песня.

In the article the author discovers and systematizes traditions and signs of national mentality in chumack's folklore.

The analysis of chumack's songs gives the opportunity to organize the conception of psychological type of chumack.

Key word: folklore, chumack's, song.

Останні десятиліття постають як період активізації інтересу до етнокультурної спадщини українського народу, та й самі звернення до фольклорних джерел характеризуються прагненням укра- 
їнців зрозуміти свою національну вдачу, зберегти й розвинути в руслі традиції матеріальний і духовний досвід народу.

С. Грица справедливо зазначає: «Нині людство тільки й починає по-справжньому вникати в глибини фольклору, розиифровувати його сутність, метафоричність, метонімічність мови, багатющу асоціативність уявлень про світ, яким людина сприймала його вже на ранніх етапах свого культурного розвитку. Тенденціям до нівелювання фольклорної традииї, що конщентрує етнічну спечифічність культури у власному ї вияві, як правило, протистоїть інша - до ї відновлення і збереження» [Грица 2000: 38].

Сьогодні надзвичайно актуальним є дослідження відображених у фольклорі засад української національної ментальності як психокультурного образу нації, як сукупності визначальних національних рис, уявлень народу про самого себе, як проявів стереотипів поведінки, що передаються з покоління в покоління 3 огляду на здатність ментальності зберігати в закодованій формі історичний досвід і визначати подальший суспільний розвиток народу, адже врахування характерних рис та особливостей національної ментальності є необхідною умовою реформування українського суспільства.

Фольклорист В. Гусєв указує на те, що «в кожну історичну епоху в залежності від структури суспільства, від стану виробників у суспільстві, змінюється зміст, форма, суспільна функиія фольклору, а також його питома вага в культурі народності, начії і людства в чілому» [Гусєв 1967: 16].

Отже, на часі перспективним і науково вмотивованим для фольклористичного пошуку є звернення до питань еволюції фольклорної спадщини соціально-побутового спрямування, визначення жанрової специфіки творів, динаміки традиції й ознак національної ментальності досліджуваного пласту фольклору.

Чумацтво - одна $з$ найяскравіших сторінок в історії українського народу. I тому роль, яку відігравав цей торгово-візницький промисел у процесі становлення економічних зв'язків України 3 
іншими державами, важко переоцінити. Проте не менш важливим $\epsilon$ і усвідомити значення чумацтва для духовного життя народу. Результати текстологічного аналізу фольклорних творів чумацької тематики дають підстави говорити про наявність у них складників національної ментальності, специфічної і ціннісної орієнтації, що робить цей пласт духовним надбанням українства.

Із розвитком української фольклористики в другій половині XIX ст. увага вчених великою мірою спрямована на дослідження народнопоетичних творів соціально-побутового змісту, їх історичних та економічних витоків, ідейних концептів. Чільне місце в цьому плані займає вивчення чумацької пісенності й відображених у ній рис національної ментальності. Так, у 1928 році виходить друком грунтовне дослідження Н. Букатевича «Чумацтво на Україні: історико-етнографічні нариси», яке стало результатом узагальнення автором досвіду його роботи в Етнографічно-діалектологічній Спілці Одеської Комісії Краєзнавства при У.А.Н. і глибокого аналізу змісту чумацьких пісень. Учений робить висновок про те, що чумаки, як соціальний прошарок, відзначаються «певними фізичними і духовними рисами» [Букатевич 1928: 2]. Дослідник студіює й відомі праці І. Рудченка, Ф. Щербини, Я. Романчука, М. Сумцова, М. Костомарова, I. Новицького, Г. Данилевського, В. Антоновича й М. Драгоманова, присвячені чумацтву як соціально-психологічному явищу, та висловлює власні критичні зауваження щодо його генези і ментальних характеристик. Н. Букатевич у своїй праці, звернувшись до історичних, економічних, соціологічних джерел, значно розширив тогочасні уявлення про різні сфери й географічні межі діяльності чумаків, розширив перелік їхніх товарів для продажу й обміну, а також уявлення про соціальні розшарування в середовищі чумацтва. Так, учений зазначає, що сіль привозили «не лише з Криму, а й галищької Коломиї, з Угорщини, з Бохні й Велички, з Удечева, <..> Покуття, <..> Кинбурзьких озер» [Букатевич 1928: 9-21], «возили найчастіше сіль та рибу, вино, горілку, тютюн, масло, полотно, горіхи, бавовну, кав 'яр, крейду, 
крупу, олію, глиняний, гончарний посуд, колеса, осі, ярма, вози, відра, чарки, баклаги для води, ложки, діжки та ін., <..> хліб, сало, свині» [Букатевич 1928: 21-46].

У пісні чумак постає фізично витривалим, упевненим у собі чоловіком, має власну гідність, уміє товаришувати. Разом із цим він володіє особливою життєвою мудрістю, по-філософськи ставиться до побутових і родинних негараздів.

Серед причин, що змушують чоловіка займатися чумацьким промислом, часто постає бажання досягти певного матеріального достатку або уникнути землеробської праці, адже він - не такий, як інші:

1) Запрягайте воли, воли рогатії,

Поїдем шукати долі багатої.

[Чумацькі пісні 1976: 175]

2) Не ходили б ми по тих дорогах, Якби було чим оплатиться.

[Чумацькі пісні 1976: 134]

3) А в Одесі добре жити

Мішком хліба не носити...

Ні за плугом, ні за ралом -

Називають мене паном.

[Чумацькі пісні 1976: 134]

4) Ой, бодай же ти, молода дівчино, та того не діждала, Ой щобб моя смоляная ручка та пшениченьку жала.

[Чумацькі пісні 1976: 154]

Бажання відкупитися від панщини або рекрутчини також постає як причина чумакування. Проте поряд із нормальним бажанням чоловіка забезпечити себе та свою родину матеріально, позбу- 
тися ненависної солдатчини пісня подає й значно глибші чинники, які сягають засад ментальності українського народу. За влучним спостереженням I. Рудченка, «чумачтво - у світобаченні народу не лише заняття, що приносить бариші, достаток, але заповітна мрія простолюдина, школа, через яку кожен повинен пройти, щоб знати життя $і$ здобути повагу» [Рудченко 1974: 447].

У переважній більшості зразків чумацької пісенності мотиви чумакування далекі від прагматизму. Спостерігаємо підкреслену відстороненість у ставленні чумака до матеріального в житті. Романтика волі, прагнення відмежуватися від одноманітності побуту, виклик долі, бажання зазнати слави - рушійні чинники у виборі діяльності чоловіка:

Ой, пускай мене, моя рідна нене, бо на те вродився, Гей, виряджай мене з вірним товариством,

щоб я не журився.

[Чумацькі пісні 1976: 64]

Чумак вважає негідним життя на одному місці, обтяжене побутовими проблемами. Він прагне долі, повної небезпек. М. Костомаров зазначав, що людина, йдучи в чумаки, задовольняла своє «прагнення життсвого простору» [Костомаров 1991: 73]. Пошук волі як духовної свободи, можливості вибирати власний життєвий шлях $\epsilon$ провідним мотивом чумацької пісні. За М. Бахтіним, дорога у фольклорі - уособлення долі людини, а вибір дороги - це вибір життєвого шляху. 3 цього погляду ідейний зміст чумацької пісенності набирає значення філософського осмислення сутності людського життя.

Розподіл обов'язків, систему стосунків у чумацькій валці побудовано за зразком Запорозької Січі. На чолі стоїть отаман або гетьман: «Отамана обирали чумаки з поміж себе. Він був найдосвідченіший, розумний $і$ вольовий... Його розпорядження було законом для кожного члена валки, хоч у всіх важливих питаннях він 
радився з товаришами. Все життя чумаків під час походу підлягало суворому розпорядку. Отаман показував илях валці, піднімав ї в дорогу, зупиняв на відпочинок, призначав сторожів, розбирав сварки між чумаками, запобігав нападу степових чужинців» [Лазуренко 2004: 26].

На думку В. Лазуренка, «чумак зберігав у собі риси, притаманні козаку» [Лазуренко 2004: 7]. Справді, чумак повинен бути вправним воїном, дотримуватися засад товариської моралі, самовіддано любити свою справу.

Із плином часу, під вагою історичних, економічних і психологічних чинників змінюється соціальний склад чумацького прошарку. Поставши з бідних селянських прошарків, чумацтво поступово набуває рис складної ієрархічної системи, де поширені наймана праця, експлуатація та не завжди справедливий розподіл заробітку.

Про соціальний склад чумацької спілки В. Лазуренко говорить так: «Щоби стати чумаком, потрібна була досить значна сума грошей. Крім пари-двох волів, треба було мати добре влаштовану мажу зо всіма приладдями до неї, икіряне покриття до неї, або хоч рогожу для покривання краму в дорозі, $i$ запас грошей на куплю краму. Цілком зрозуміло, що чумаки-хазяїни (не наймити) походили з досить заможних шарів» [Лазуренко 2004: 55].

Із розвитком торгівельних міст (Херсона, Миколаєва, Таганрогу, Маріуполя, Одеси), опануванням берегів Чорного моря, приєднанням Росією Криму (1783 р.), встановленням безпосередніх торговельних зв'язків із західноєвропейськими країнами через щойно засновані порти зростає роль чумацької промисловості. Проте поступово через ряд причин економічного плану (високі дорожні витрати й низькі ціни на сіль, інтенсивне будівництво залізниць, розвиток водного транспорту та ін.), чумацтво занепадає. Н. Букатевич зазначає, що в 30-х роках XIX століття виникають «...чyмачькі валки нового типу, валки хазяйські, замість ватаг типу запорозького, які мали на собі відбиток військової організації $i$ разом з тим були торговельно-візнищькими товариствами, що 
торгували й перевозили свій крам. Інші - "незаможні" чумаки складали ватаги візнищькі, які перевозили виключно чужий крам» [Букатевич 1928: 63].

Усвідомлення безперспективності подальшої діяльності, пригнічений душевний стан - провідні мотиви пізніших зразків чумацької пісні. Тужливий настрій супроводжує чумака, іноді змушує звернутися до чарки:

1) Запив чумак, запив бурлак, Запив, зажурився.

Ой тим же він зажурився Без долі вродився.

[Чумацькі пісні 1976: 218]

2) Ой зачвіла червона калина

Та у темному лузі,

Тепер моя бідна головонька

I серденько в тузі.

[Чумацькі пісні 1976: 65]

На думку В. Лазуренка, «чумачтво у XVI-XIX столітmяx стало для нашої начії однією з форм самосиілення. Якщо козачтво оберігало наші землі зі зброєю, кобзарі оживляли духовне пробудження за допомогою кобзи й пісні, то чумаки тримали, якщо можна так висловитись, економічні важелі. Україна через постійні війни й грабунки потерпала в ті часи від господарської розрухи. Не маючи змоги налагодити чіткі державні структури, природнии організм начії змушений був вишукувати інші форми самосиілення. Такою формою і стало чумацтво» [Лазуренко 2004: 3].

Постать чумака в народній свідомості романтична і по-своєму трагічна. А тому зміст чумацької пісні майже завжди виводить ії за межі побутових описів життя людей певної професії. Чумак як соціальний і фольклорний тип із його прагненням свободи, мужністю, вмінням товаришувати, здатністю мислити небуденно все ж у біль- 
шості випадків позбавлений високої історичної мети, оскільки намагання людини знайти себе, своє місце в суспільстві, прагнення самоутвердження, самоусвідомлення і всі провідні ідеї чумацького циклу пісенності, що відображають трансформацію козацьких патріотичних ідеалів зводиться до ідеалів людини, яка перш за все прагне реалізуватися як особистість.

\section{БІБЛІОГРАФІЯ}

Букатевич 1928 - Букатевич Н. Чумацтво на Україні : іст.-етнограф. нариси. Одеса, 1928. - 96 с.

Грица 2000 - Грица С. Й. Фольклор у просторі та часі : вибрані статті / Софія Йосипівна Грица ; ред. О. С. Смоляк. - Тернопіль : Астон, 2000. - 228 с. Гусев 1967 - Гусев В. Эстетика фольклора. - М. : Наука, 1967. - С. 267-312.

Костомаров 1991 - Костомаров Н. И. Две русские народности / Николай Иванович Костомаров. - К. ; Харьков : Майдан, 1991. -72 с.

Лазуренко 2004 - Лазуренко В. М. Каравани українського степу / В. М. Лазуренко, Ю. М. Вовкотруб. - 2-ге вид., доп. - Черкаси : Ваш дім, 2004. - 92 с.

Рудченко 1974 - Рудченко И. Я. Чумаки в народных песнях: Этнографический очерк // Чумацкие народные песни. - К., 1974. - С. 17-57.

Чумацькі пісні 1976 - Чумацькі пісні. - К. : Наукова думка, 1976. - 461 с. 